\title{
A Literature Review on the Relationship
}

\section{Between Service Quality and Customer Loyalty}

\author{
Yingsheng $\mathrm{Du}^{1} \&$ Youchun Tang ${ }^{2}$ \\ ${ }^{1}$ School of Management, Shanghai University of Engineering Science, Shanghai, China \\ ${ }^{2}$ School of Management, Shanghai University of Engineering Science, Shanghai, China \\ Correspondence: Youchun Tang, School of Management, Shanghai University of Engineering Science, Shanghai, \\ China. E-mail: tyctyc2003@126.com
}

Received: July 31, 2014

Accepted: August 4, 2014

Online Published: August 12, 2014

doi: 10.5430/bmr.v3n3p27

URL: http://dx.doi.org/10.5430/bmr.v3n3p27

\begin{abstract}
Customer loyalty is the most precious intangible assets of modern enterprise. High loyalty is not only the key of enterprise competition to win, but also the fundamental guarantee of enterprise's stability. In the era of service economy, improving the service quality has always been considered as one of the effective ways to improve customer loyalty. To a large extent, service quality can affect customer loyalty to the enterprise. The influence can be direct, and it can also be indirect. This paper aims to sum up a series of function mechanism between service quality and customer loyalty through the analysis of domestic and foreign literature, which will provide some ideas of building model in the future research.
\end{abstract}

Keywords: Service quality, Customer loyalty, Function mechanism

\section{Introduction}

In the field of modern service research, service quality and customer loyalty are always the focus. The study has found that customer loyalty is much more important than market share in determining the profits. When customer loyalty rise $5 \%$, the profits will rise $25 \% \sim 25 \%$. In the service industry, service quality is one of the most important factors that affect customer loyalty. So the research of the mechanism between the between service quality and customer loyalty has important significance in promoting the healthy development of China's service industry.

First of all, this paper analyses the definitions of service quality and customer loyalty based on the existing research at home and abroad. Secondly, this paper will summarize the research on the relationship between service quality and customer loyalty from the direct and indirect aspects. This paper will provide some ideas for the future research in this field.

\section{Relevant Concepts}

\subsection{Service Quality}

About the definition and components of service quality, different scholars develop their own opinions from different angles.

Parasuramn, Zeithaml \& Berry (1985) pointed out that consumers' perception of service quality is the gap between the expectation of universal level service provider's service performance and the real performance perception of a specific enterprise. $t$ can be expressed by the formula:

\section{Service quality $=$ Perceived performance -Expectation of Service}

Parasuraman, Zeithaml \& Berry (1988) identified five major dimension of customer service quality:

1) Tangibles: Service place, facility and the appearance of service staffs; 2 ) Reliability: The ability of providing promised service to customers reliably and correctly; 3 ) Responsiveness: The will of service staffs to help customers and to provide real-time service; 4) Assurance: Service staffs are professional, polite and reliable; 5) Empathy: Companies care customers and provide some other special attentions.

Hou Xingqi (2008) thinks that service quality is customer's subjective cognition, not objective evaluation, it is the evaluation on service providers after comparing the gap between the desired service quality in advance and the actual service quality consumers receive. 
Zou Jianping (2010) divided the express delivery service quality into communication quality, order quality, delivery quality, arrival quality and order discrepancy handling quality in the study of express service quality.

Lin Xiaorui (2012) divided the express delivery service quality into interaction of logistics service quality, operation of the logistics service quality and cost of logistics service quality.

To sum up, definition and components of service quality in different field are always not same. But the view that service quality is the gap of customers' expectation and the actual perception of service quality can basically be able to get approval from most people.

\subsection{Customer Loyalty}

About the definition and components of customer loyalty, also there are some different opinions.

Oliver (1997) believed that customer loyalty is the customer's deep commitment to the partial products and services, the customer will purchase the product consistently and stick to a same brand or a series of products or service that belong to one brand. And the customer will not transfer to other brands under the influence of the change of market situation and the competitive marketing power. It can be divided into attitude loyalty and behavior loyalty.

Gronholdt, Martensen \& Kristensen (2000) pointed out that the customer loyalty is composed of four indexes, including the customer repurchase intention, price tolerance, willingness of recommending company or products to others and customer's cross-buying intention.

Yao Dan (2011) thinks that no matter the evaluation from multidimensional or overall, the connotation of customer loyalty should not only reflect the customer's behavior characteristics (such as repeat purchase), but also the emotional characteristics of customer loyalty (such as customer's love of for products or service, and the love should be positive, active and sustainable).

To sum up, customer loyalty includes two aspects: attitude loyalty and behavior loyalty. Attitude loyalty refers to a positive psychological tendency that customers have to enterprise's products or service; behavioral loyalty refers to the customer's repeat purchase behavior.

\section{Relationship between Service Quality and Customer Loyalty}

\subsection{Direct Influence}

About the relationship between service quality and customer loyalty, lots of views have been put forward by scholars. Some scholars have proved that service quality can directly affect customer loyalty through empirical research.

Parasuraman, Zeithaml \& Berry $(1985,1988)$ pointed out that the relation between service quality and customer behavioral intention is closely, customer's final action will be decided by service quality. And the service quality will affect customer willingness to recommend to others. As we know, recommendation intention is an important index of customer loyalty. So there is a positive correlation between service quality and customer loyalty.

Wang Chunxiao, Wen Biyan \& Jiang Caifen (2001) pointed out that service quality has an influence on customer behavioral intention not only through a significant indirect effect, but also a significant direct effect after the empirical study of three travel agencies in Guangdong.

Han Xiaoyun \& Wang Chunxiao (2003) pointed out that service quality has a direct impact on customer's cognition and emotional loyalty after the investigation of six classes of service enterprises: hotel, bank, hospital, civil aviation, mobile communications, beauty salon.

Chen Hongcui (2008) proved that the dimensions of customer service quality: Tangibles, Responsiveness and Empathy have a direct impact on customer loyalty after the investigation of training industry (Figure 1). 


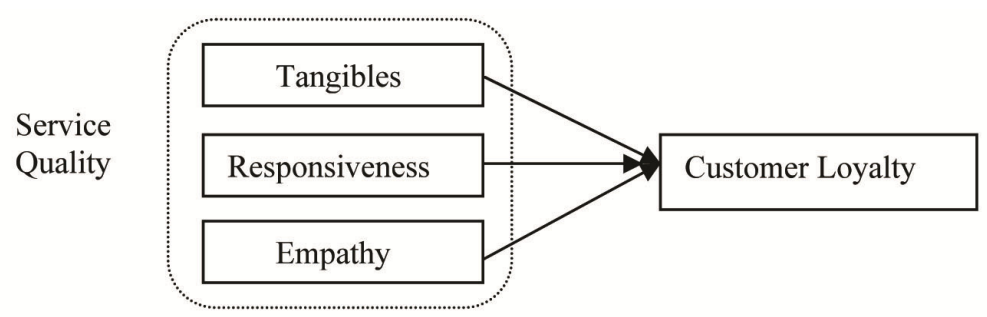

Figure 1. Service quality-Customer loyalty model of training industry

\subsection{Indirect Influence}

\subsubsection{Take Customer Satisfaction as Intervening Variable}

In the study of the influence of service quality on customer loyalty, lots of scholars have introduced some intervening variables. Customer satisfaction is the most commonly used intervening variable.

Kotler (1999) believed that customer satisfaction is the degree of customer's level of pleasant feeling. It stems from the comparison of the perception of products performance and personal expectation of products.

Caruana (2000) put forward a model that contained service quality, customer satisfaction and customer loyalty after the review of the three aspects (Figure 2). And he verified the assumptions through the research of the retail bank.

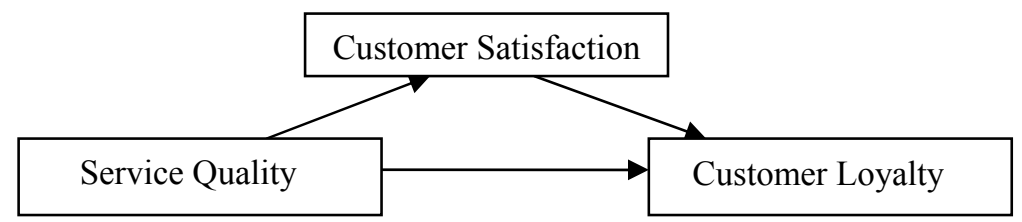

Figure 2. Relationship between Service quality, customer satisfaction and customer loyalty

The result of the research showed that service quality had a direct influence on customer loyalty, but when customer satisfaction was introduced, service quality would affect service loyalty through customer satisfaction indirectly, customer satisfaction would play an intervening role.

Hou Xingqi (2008) also took customer satisfaction as intervening variable in the study of high star-level hotel customer loyalty (Figure 3).

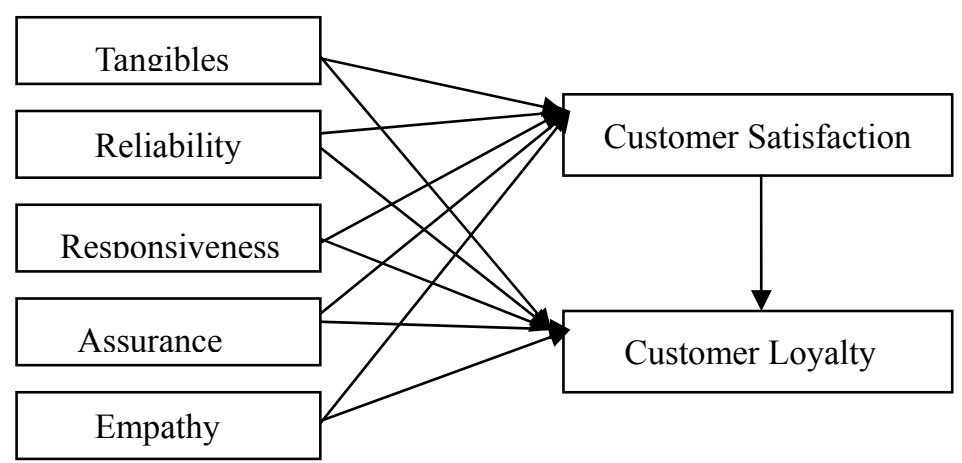

Figure 3. Customer loyalty model of high star-level hotel

From the result of the study, there is a significant positive relationship among the overall service quality, customer satisfaction and customer loyalty. When customer feels satisfied, it will positively influence customer's loyalty. A satisfied customer of hotel will be loyal.

Deng Yingru (2013) built a model that contains the service quality of catering enterprise, group-buying website service quality, customer satisfaction and customer loyalty in the study of the relationship between service quality and customer loyalty of catering group-buying (Figure 4). 


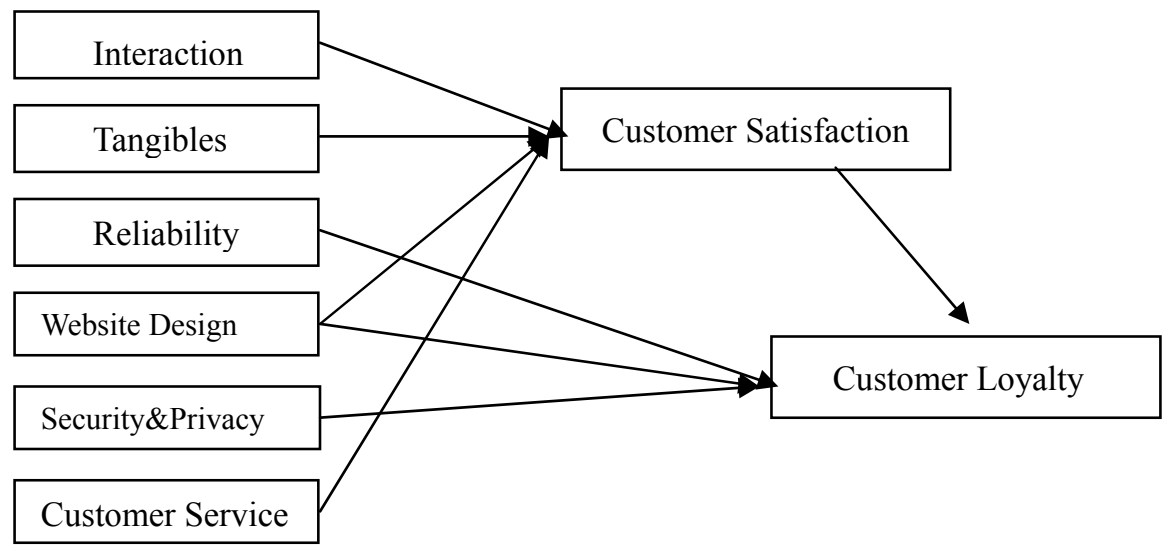

Figure 4. Customer loyalty model of catering group-buying

The research proves that website service quality of catering group-buying will produce a positive effect on catering enterprises. At the same time, the service quality of both catering enterprises and group-buying website has positive effect on customer loyalty in catering enterprises through customer satisfaction.

\subsubsection{Take Customer Perceived Value as Intervening Variable}

The relationship among service quality customer perceived value and customer loyalty has been studied by scholars for a long time. The conclusion is basically consistent: Service quality will affect customer loyalty through customer perceived value.

Zeithaml, Parasuramn \& Berry thought that customer perceived value is the overall evaluation of product utility based on the perceived gains and losses. This view is widely shared.

Based on Zeithaml, Parasuramn, Berry's definition of customer perceived value, Yao Dan (2011) pointed that for different customers, the perceived gains and losses is different.

Bolton \& Drew (1991) found that service quality could influence customer's purchase intention through the customer perceived value after the telephone survey of the telecommunication service.

Wakefield \& Barnes (1996) drew a conclusion that perceived service environment quality will affect the repeat purchase intention through perceived value after the survey of entertainment service industry.

Grewal, Monroe \& Krishnan (1998) pointed out that service quality could influence customer's purchase intention through the customer perceived value after the survey of bicycle sales service.

As we know, repeat purchase intention is an important indicator to measure customer loyalty. So to a certain extent, the researches above have confirmed that the service quality can affect customer loyalty through perceived value.

Yao Dan (2011) took customer perceived value as the intervening variable in the study of catering group-buying customer loyalty (Figure 5).

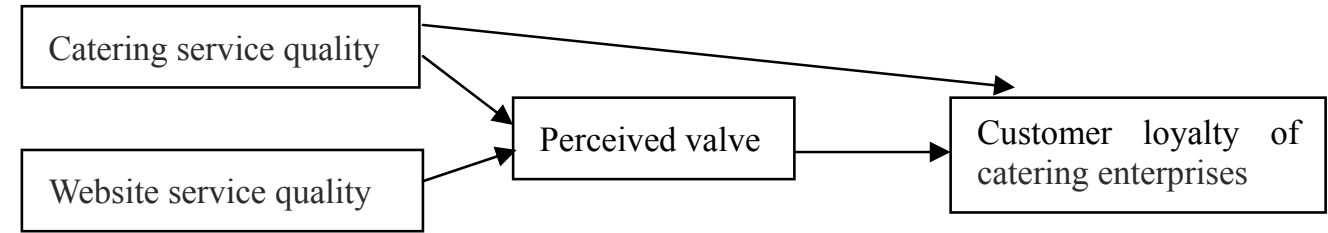

Figure 5. Customer loyalty model of catering group-buying

Supported by a large number of survey data, the research proved the catering enterprises service quality has a positive effect on customer loyalty through the customer perceived value be perceived value a positive impact on.

\subsubsection{Take Customer Perceived Value and Customer Satisfaction as Intervening Variables}

Scholars proved that customer perceived value could not only be the intervening variable separately, but also could be taken as intervening variable together with customer satisfaction. And under normal circumstances, customer perceived value will affect customer satisfaction indirectly through customer loyalty. 
Dong Dahai \& Dong Yufang (2004) though that customer perceived value and customer satisfaction have a positive and linear effect on customer behavior. The research also proved that the customer's perceptive value is the most important cause of customer loyalty.

Peng Yan (2006) also took customer perceived value and customer satisfaction as intervening variables in the study of the relationship between perceived service quality and customer loyalty of online securities trading (Figure 6).

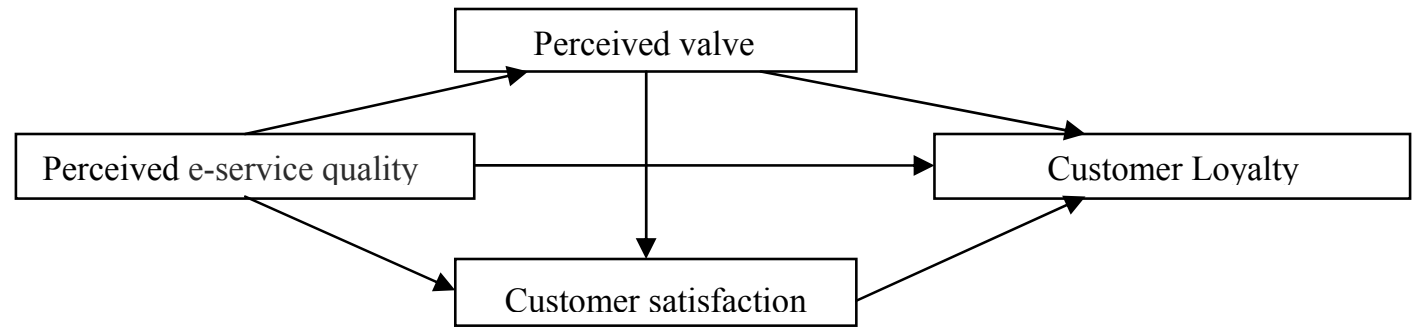

Figure 6. Customer loyalty model of online securities trading

Through the empirical research, the study proved that the customer perceived e-service quality could affect customer loyalty through customer perceived value and customer satisfaction.

\subsubsection{Take Customer Satisfaction and Customer Trust as Intervening Variables}

In the study of customer loyalty formation mechanism, many scholars took customer satisfaction and customer trust as intervening variables; they believed that the service quality did affect customer loyalty through customer satisfaction and customer trust.

About the definition of customer trust, different scholars defined it from different angles. Moorman (1993) defined trust as a kind of confidence in trading partners that they are willing to rely on. Morgan, Hunt (1994) defined trust as the confidence of trading partners' reliability integrity. All these definitions emphasized the importance of confidence and reliability to trust.

Chang Yaping, Liu Yanyang \& Yan Jun (2009) define the concept of network service quality and its components under the environment of $\mathrm{B} 2 \mathrm{C}$ e-commerce based on the transaction process of online store. They also built a model of the mechanism that network service quality influences customer loyalty and did the related empirical research (Figure 7).

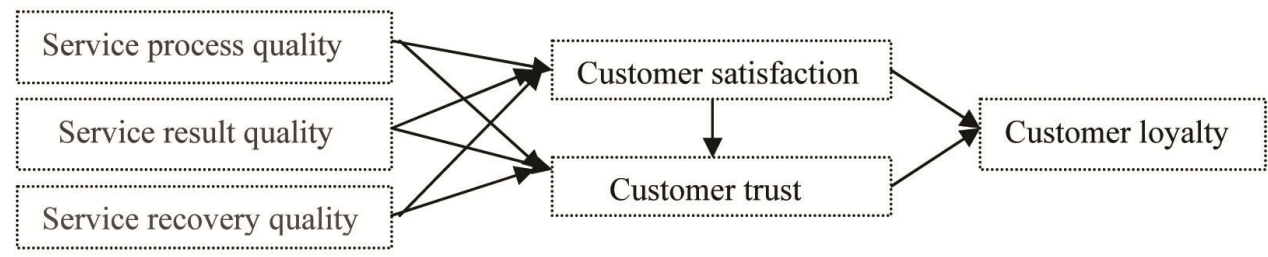

Figure 7. Model of relationship between $\mathrm{B} 2 \mathrm{C}$ network service quality and customer loyalty

Zou Jianping (2010) build a initial model relationship between express service quality, customer satisfaction, customer trust customer loyalty in the express industry study. Through empirical research, the final relationship model of express industry was built (Figure 8).

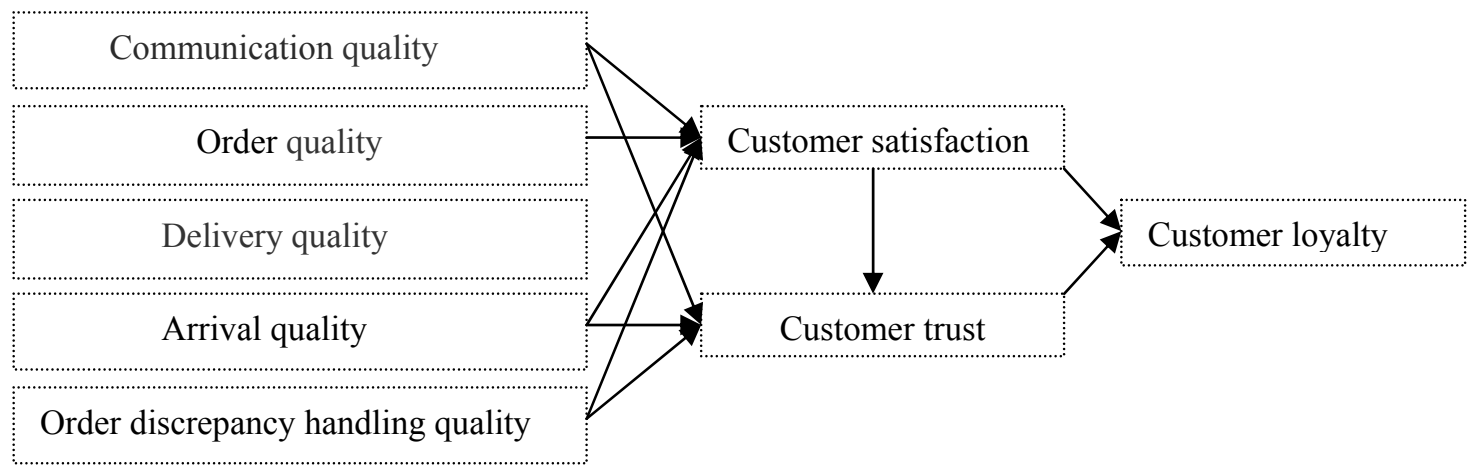

Figure 8. Relationship model between Express Service Quality and Customer Loyalty 
From the final model of the study we know that different dimensions of express service quality can not only affect customer loyalty through the two intervening variables customer satisfaction and customer trust separately, but also can affect customer loyalty together with the two intervening variables.

\section{Conclusion}

This paper conducted a literature review of function mechanism between service quality and customer loyalty. Through the analysis of domestic and foreign literature, this article divided the effect service quality has on customer loyalty into direct effect and indirect effect. In the indirect part, scholars usually introduced one or more intervening variables, such as customer satisfaction, customer trust and customer perceived value, etc. Because research areas are not the same, different scholars would select different intervening variables and the number of the intervening variables would be also different.

Because of the limitation of the length of paper, this paper could not summarize all the literatures in this field. The future literature review in this field could try to summarize some models contain other intervening variable so as to better show the research status in this field to the scholars.

In the research of the relationship between service quality and customer loyalty, there is no fixed research model. In order to serve the studies, scholars should build their own research model based on the existing literature results in the future research.

\section{References}

Bolton Ruth N. \& Drew James H. (1991). A multistage model of customers' assessments of service Quality and value. The Journal of Consumer Research, 13, pp. 375-384. http://dx.doi.org/10.1086/208564

Caruana, A., Money, A. H. \& Berthon, P. R. (2000). Service quality and satisfaction-the moderating role of value. European Journal of Marketing, 34(11/12), pp. 1338-1353. http://dx.doi.org/10.1108/03090560010764432

Chang Yaping, Liu Yanyang \& Yan Jun. (2009). Research of the function mechanism between B2C network service quality and customer loyalty. Journal of Systems Science and Information, 06, pp. 94-106.

Chen Hongcui. (2008). Research of the influence service quality on customer loyalty_Take chenzhou English industry for example. Central South University.

Deng Yingru. (2013). Study on the Relationship between Group-buying Service Quality and Customer Loyalty in Catering Industry. Zhengjiang University.

Dong Dahai \& Dong Yufang. (2004). Customer value: an important antecedent cause of competitive advantage. Journal of Management Sciences, 05, pp. 43-47.

Grewal D, Monroe KB \& Krishnan R. (1998). The effects of price-comparison advertising on buyers' perceptions of acquisition value, transaction value, and behavioral intentions. The Journal of Marketing, 62, pp. 46-59. http://dx.doi.org/10.2307/1252160

Gronholdt, L., Martensen, A. \& Kristensen, K. (2000). The relationship between customer satisfaction and loyalty: cross-industry differences. Total Quality Management, 11(4-6), pp.509-514. http://dx.doi.org/10.1080/09544120050007823

Han Xiaoyun \& Wang Chunxiao. (2003). The relationship between customer satisfaction and loyalty of service enterprises. Tsinghua University Press.

Hou Xingqi. (2008). The Study on Service Quality Customer Satisfaction and Loyalty. Shandong University.

Kotler Philip. (1999). Kotler on marketing: How to create, win, and dominate markets. New York: The Free Press.

Lin Xiaorui. (2012). Research on relationship between the service quality of the third party logistics and the customer loyalty to the seller. North University of China. 
Moorman C, Deshpande R \& Zailman G. (1993). Factors affecting trust in market research relationship. Journal of Marketing, 57(1), pp. 81-101. http://dx.doi.org/10.2307/1252059

Morgan RM \& Hunt SD. (1994). The commitment and trust theory in relationship marketing. Journal of Marketing, 58(3), pp.20-38. http://dx.doi.org/10.2307/1252308

Oliver, R.L. (1997). Satisfaction: A Behavioral perspective on the Consumer. New York : McGraw-Hill.

Parasuraman, A., Zeithaml, V. A. \& Berry, L.L. (1985). A Conceptual Model of Service Quality and its Implications for Future Research. Journal of Marketing, 49, pp. 41-50. http://dx.doi.org/10.2307/1251430

Peng Yan. (2006). Research of the relationship between online securities trading Customer perceived e-service Quality And Customer loyalty. Huazhong University of Science and Technology.

Wakefield Kirk L. \& Barnes James H. (1996). Retailing hedonic consumption: a model of sales promotion of a leisure service. Journal of Retailing, 72(4), pp. 409-427. http://dx.doi.org/10.1016/S0022-4359(96)90021-4

Wang Chunxiao, Wen Biyan \& Jiang Caifen. (2001). Service quality, consumption value, passenger satisfaction and behavioral intention. Nankai Business Review, 06, 11-15.

Yao Dan. (2011). Empirical Research of Perceived Value as a Mediator between Group-buying Service Quality and Customer loyalty in Catering Industry. Nanjing University.

Zou Jianping. (2010). Research on Express Service Quality and Its Relationship with Customer Loyalty. Xidian University. 